(C) 1990 ISIJ

技術報告

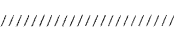

\section{炭素飽和溶鉄相からのキッシュ・ グラファイトの浮上}

井上芫* 水渡 英 昭 $* 2$

Flotation of Kish Graphite Precipitated from Carbon-saturated Iron Melt

Ryo INous and Hideaki SutTo

\begin{abstract}
Synopsis :
The flotation of carbon precipitated from carbon-saturated iron melt has been studied as a function of temperature drop, cooling rate, stirring and sulfur content in metal. Under the experimental conditions such as temperature $\left(1450^{\circ} \mathrm{C}\right)$, the temperature drop $\left(50 \sim 240^{\circ} \mathrm{C}\right)$ and the cooling rate $\left(14.6 \sim 150^{\circ} \mathrm{C} / \mathrm{h}\right)$, the amount of carbon floated to the top of the metal phase was observed to increase with increasing the degree of the temperature drop and with decreasing the cooling rate. The rate of flotation for the flakytype graphite (Kish graphite) was much faster than that for the sphere-type precipitated carbon. Furthermore the rate of flotation was accelerated by stirring, and increased by the addition of sulfur.
\end{abstract}

Key words : flotation; kish graphite ; precipitated carbon ; carbon-saturated iron.

\section{1. 緒}

\section{言}

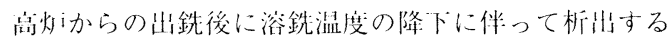
鱗片状の過飽和览絭はキッシュ・グラファイト（以下 $\mathrm{KG}$ と称す)と呼ば机ている。萝考らは脚報”に扔いて， 奌炏系スラグ，脱烓スラグ，ソーダ系スラグおよび含 $\mathrm{CaF}_{2}$ 系スラグからの $\mathrm{KG}$ の浮上分離に関する研究を 行った。その絬果，苂素飽和漁鉄とスラグが其低する埸 介、メタル相から析门したKGはスラグーメタル界面の メタル側に集積すること，摚排などによりいったんスラ グ中に人り达んだ $\mathrm{KG}$ はスラグト隡に浮上することを 見出した。さらに，KG 衣自の SEM 観祭から，スラグ

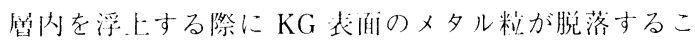
とがわかった。

本研究では $\mathrm{KG} の$ の收率を高めるための基礎的知昌 を街ることを目的とし，荻素飽利溶鉄中の $\mathrm{KG} の$ 浮卜

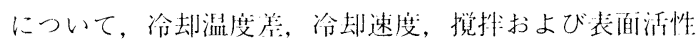
元装である硫黄濃度の影響を明らかにしたので報告す る.

\section{2. 実 験 方 法}

$\mathrm{LaCrO}_{3}$ 製発熱体を们する縦型抵抗灼索用い, 脱酸
Ar 気流中 $(150 \mathrm{ml} / \mathrm{min})$ で溶解を行った。赺験温度は PID 自動温度溒節器により設走した。あらかじめ黑鎑

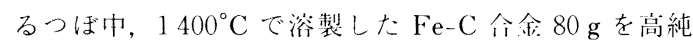
度 $\mathrm{Al}_{2} \mathrm{O}_{3}$ るつは（内栙 $24 \mathrm{~mm}$, 高さ $150 \mathrm{~mm}$ ) 中に装人 L, $1450^{\circ} \mathrm{C}$ で浴解後, 緻密な离純度照鉛棒( 通径 $8 \mathrm{~mm}$, 产さ $300 \mathrm{~mm}$ ) で搅排しながら $30 \mathrm{~min}$ 保持した。 その後 黑鉛棒を取り出し, メ夕ル表淌にCが浮遊していない ことを確認してから，冷却速度 14.6，60または $150^{\circ} \mathrm{C} / \mathrm{h}$ で温度降下を開始した。温度降下中摚抖する笑 験では，冷却開始加ら㴊起温度（以下，间化温度と称す） 到達 1 min 前まで高純度 $\mathrm{Al}_{2} \mathrm{O}_{3}$ 棒により約 100 r.p.m. で摚排を行った。因化湿度に到達後るつぼごと炉外に取 り出し、るつほ外壁を流水中に浸溑しながらメタル表目 にHe を吹き付けて凝活させた。试料上部に付着してい る $\mathrm{KG}$ を取り除いた後, 上部から約 $1 \mathrm{~mm}$ のメタル部 分を研磨して除去した。試料を上部から縦力们に4〜7 分割し，各部について酸素父流中燃烧一電量滴是法 (JIS-Z-2615) による半C 濃度分析抢上び顕微鏡観祭 を行った。

一分温度で炭素飽和浴鉄に精製 KGを添加した実験 では， $\mathrm{Al}_{2} \mathrm{O}_{3}$ るつぼ底産に精製 $\mathrm{KG} 0.5 \mathrm{~g}$ を人れ，あ らかじめ黒鉛るつぼ中, $1350^{\circ} \mathrm{C} て ゙$ 溶製した Fe-C 今金

平成元年 4 月本会溝滨大会にて発衣 为元年 7 月 7 月受付 (Received July 7, 1989)

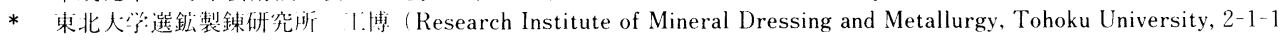
Katahira Aoba-ku Sendai 980)

*2 東北大学選鉱慗鋉研究䜣 Ph. D (Research Institute of Mineral Dressing and Metallurgy, Tohoku University) 
をその上に㯰いた。 $1354^{\circ} \mathrm{C} て ゙$ 加熱溶解後, 高純度 $\mathrm{Al}_{2} \mathrm{O}_{3}$ 棒で搅排して KG をメタル中に分散させ $5 \mathrm{~min}$ 保持した，精製 KG とは，製鉄所現場で採取された $\mathrm{KG}$ を $10 \% \mathrm{HF}-27 \% \mathrm{HCl}$ 水溶液中で $1 \mathrm{~h}$ 募沸し, 蒸留水で 洗浄後軲燥㧍よび節分けを行ったものであり，0.25〜 $1.0 \mathrm{~mm}$ の大きさで闹定 C 濃度 $98.4 \%$ のものを用い た。

\section{3. 結果および考察}

本実験条件下でのメ夕ル試料中各部のC濃度を Table 1 に与える.

摚找せずに冷却した策験におけるメタル中の析出 $\mathrm{C}$ の分布状態について顕微鏡観祭を行った，その結果，冷 却速度 $150^{\circ} \mathrm{C} / \mathrm{h}$ では楇化温度 $1392^{\circ} \mathrm{C}$ の場合, 厚さ 3 $\sim 10 \mu \mathrm{m}$, 主さ $30 \sim 200 \mu \mathrm{m}$ の細かな $\mathrm{KG}$ がメ夕ル浴上 部よりその深さの約 $80 \%$ までの間で認められ，㨁径 3 ～30 $\mu \mathrm{m}$ の球状に近い析出 $\mathrm{C}$ がメタル全体に分优して いた。周化温度が低下すると基に $\mathrm{KG}$ は厭く長くなり， $\mathrm{KG}$ が認められるメタル浴深さも上部に移動しており, 固化温度 $1210^{\circ} \mathrm{C}$ では㫗さ $50 \sim 200 \mu \mathrm{m}$, 長さ 400
$1000 \mu \mathrm{m}$ の $\mathrm{KG}$ がメタル浴深さの約 $40 \%$ まで存在し た。このことから KGは温度降下に伴って成長しなが ら浮上することがわかる．直径 $10 〜 30 \mu \mathrm{m}$ の球状に近 い析出 Cはメタル全体に分布していた。一方，冷却速

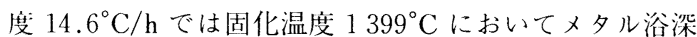
さの約 $65 \%$ まで $\mathrm{KG}$ が分散していたが，估化温度 $1349^{\circ} \mathrm{C}$ では KG はメタル表面近傍に認められるにすぎ なかった、いずれの実験でも凝固時の $\mathrm{He}$ 吹付けにより $\mathrm{KG}$ がるつぼから飛散冕失することが観察された。また， メタル全体に球状に近い析出 $\mathrm{C}$ が分布し，いくつかの 実験においてメタル底部の $\mathrm{Al}_{2} \mathrm{O}_{3}$ るつぼとの界面にる つぼに付着するように微かに $\mathrm{KG}$ が羿められたことか

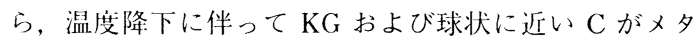
ル全体から析出し，KGは浮上したと思われる.

炭素飽和溶鉄および黒鉛の比重はそれぞれ 6.6〜 7.1 $\mathrm{g} / \mathrm{cm}^{32)}$ および $2.25 \mathrm{~g} / \mathrm{cm}^{33)}$ であり，この比重差の故に 析出した $\mathrm{KG}$ および球状に近い $\mathrm{C}$ は容易に浮上すると 考えられる。C 飽和溶鉄を冷却する場合，冷却速度が 小さければ初晶として鱗片状の $\mathrm{KG}$ が現れる ${ }^{4)}$. メタル 中に球状に近い析出 $\mathrm{C}$ が分布し， $\mathrm{KG}$ がメタル上部に

Table 1. Analysed carbon content in metal for various experimental conditions.

\begin{tabular}{|c|c|c|c|c|c|c|}
\hline No. & $\begin{array}{c}\text { Initial } \\
\text { temperature } \\
\left({ }^{\circ} \mathrm{C}\right)\end{array}$ & $\begin{array}{l}\text { Quenching } \\
\text { temperature } \\
\left({ }^{\circ} \mathrm{C}\right)\end{array}$ & $\begin{array}{c}\text { Cooling } \\
\text { rate } \\
\left({ }^{\circ} \mathrm{C} / \mathrm{h}\right)\end{array}$ & $\begin{array}{l}\text { Depth } \\
(\mathrm{mm})\end{array}$ & $\underset{(\mathrm{g})}{\text { Weight }}$ & {$[\% \mathrm{C}]$} \\
\hline 1 & 1453 & 1392 & 150 & $\begin{array}{r}1 \sim 7.5 \\
8.0 \sim 12.5 \\
13.0 \sim 20.0 \\
20.5 \sim 27.7 \\
28.2 \sim 35.1 \\
35.6 \sim 45.0\end{array}$ & $\begin{array}{r}8.308 \\
7.968 \\
18.976 \\
13.268 \\
12.368 \\
15.380\end{array}$ & $\begin{array}{l}4.75 \\
4.93 \\
5.03 \\
5.05 \\
5.05 \\
4.97\end{array}$ \\
\hline 2 & 1453 & 1399 & 14.6 & $\begin{array}{r}1 \sim 7.7 \\
8.2 \sim 15.8 \\
16.3 \sim 23.8 \\
24.3 \sim 30.6 \\
31.1-36.8 \\
37.3 \sim 45.8\end{array}$ & $\begin{array}{l}13.484 \\
15.450 \\
11.142 \\
12.656 \\
12.977 \\
10.290\end{array}$ & $\begin{array}{l}4.93 \\
5.06 \\
5.03 \\
4.92 \\
4.90 \\
4.78\end{array}$ \\
\hline $3-1$ & 1450 & 1348 & 150 & $\begin{array}{r}1 \sim 4.2 \\
4.7 \sim 10.8 \\
11.3 \sim 15.5 \\
16.0 \sim 19.5 \\
20.0 \sim 23.2 \\
23.7 \sim 27.2 \\
27.7 \sim 39.8\end{array}$ & $\begin{array}{r}5.492 \\
14.952 \\
11.780 \\
10.336 \\
8.940 \\
7.216 \\
17.028 \\
\end{array}$ & $\begin{array}{l}4.75 \\
4.85 \\
4.95 \\
4.93 \\
4.96 \\
4.94 \\
4.90 \\
\end{array}$ \\
\hline $3-2$ & 1453 & 1348 & 150 & $\begin{array}{r}1 \sim 5.8 \\
6.3 \sim 11.4 \\
11.9 \sim 18.6 \\
19.1 \sim 24.8 \\
25.3 \sim 32.0 \\
32.5 \sim 40.0 \\
40.5 \sim 45.1\end{array}$ & $\begin{array}{r}10.416 \\
9.218 \\
12.100 \\
10.229 \\
12.162 \\
13.602 \\
8.273 \\
\end{array}$ & $\begin{array}{l}4.78 \\
4.92 \\
4.98 \\
4.98 \\
4.94 \\
4.92 \\
4.90\end{array}$ \\
\hline 4 & 1453 & 1349 & 60 & $\begin{array}{r}1 \sim 3.3 \\
3.8 \sim 11.7 \\
12.2 \sim 16.5 \\
17.0 \sim 21.1 \\
21.6 \sim 27.5 \\
28.0 \sim 33.1 \\
33.6 \sim 46.1\end{array}$ & $\begin{array}{r}4.158 \\
14.219 \\
7.782 \\
7.393 \\
10.674 \\
9.139 \\
22.639\end{array}$ & $\begin{array}{l}4.78 \\
4.82 \\
4.95 \\
5.03 \\
4.97 \\
4.95 \\
4.94\end{array}$ \\
\hline 5 & 1451 & 1349 & 14.6 & $\begin{array}{r}1 \sim 8.5 \\
9.0 \sim 18.8 \\
19.3 \sim 27.4 \\
27.9 \sim 36.8 \\
37.3 \sim 50.2\end{array}$ & $\begin{array}{r}8.965 \\
11.941 \\
15.321 \\
15.226 \\
24.372\end{array}$ & $\begin{array}{l}5.40 \\
5.10 \\
4.67 \\
4.58 \\
4.62\end{array}$ \\
\hline
\end{tabular}

\begin{tabular}{|c|c|c|c|c|c|c|}
\hline No. & $\begin{array}{c}\text { Initial } \\
\text { temperature } \\
\left({ }^{\circ} \mathrm{C}\right)\end{array}$ & $\begin{array}{c}\text { Quenching } \\
\text { temperature } \\
\left({ }^{\circ} \mathrm{C}\right)\end{array}$ & $\begin{array}{c}\text { Cooling } \\
\text { rate } \\
\left({ }^{\circ} \mathrm{C} / \mathrm{h}\right)\end{array}$ & $\begin{array}{l}\text { Depth } \\
(\mathrm{mm})\end{array}$ & $\underset{(\mathrm{g})}{\text { Weight }}$ & {$[\% \mathrm{C}]$} \\
\hline 6 & 1452 & 1210 & 150 & $\begin{array}{r}1 \sim 7.6 \\
8.1 \sim 14.3 \\
14.8 \sim 20.6 \\
21.1 \sim 28.1 \\
28.6 \sim 39.4\end{array}$ & $\begin{array}{l}12.179 \\
16.209 \\
14.879 \\
18.173 \\
13.652\end{array}$ & $\begin{array}{l}4.77 \\
4.75 \\
4.73 \\
4.72 \\
4.70\end{array}$ \\
\hline $7^{*}$ & 1452 & 1348 & 150 & $\begin{array}{r}1 \sim 5.9 \\
6.4 \sim 14.2 \\
14.7 \sim 21.9 \\
22.4 \sim 33.3\end{array}$ & $\begin{array}{l}10.104 \\
11.240 \\
14.536 \\
13.828\end{array}$ & $\begin{array}{l}4.76 \\
4.83 \\
4.82 \\
4.82\end{array}$ \\
\hline $8^{*}$ & 1451 & 1349 & 60 & $\begin{array}{r}1 \sim 6.0 \\
6.5 \sim 11.1 \\
11.6 \sim 15.0 \\
15.5 \sim 19.1 \\
19.6 \sim 23.4 \\
23.9 \sim 28.0 \\
28.5 \sim 39.0\end{array}$ & $\begin{array}{r}6.412 \\
8.641 \\
8.123 \\
8.852 \\
8.635 \\
8.480 \\
13.308\end{array}$ & $\begin{array}{l}4.67 \\
4.86 \\
4.86 \\
4.87 \\
4.85 \\
4.85 \\
4.77\end{array}$ \\
\hline $9 * 2$ & 1354 & 1354 & 0 & $\begin{array}{r}1 \sim 7.3 \\
7.8 \sim 12.8 \\
13.3 \sim 20.2 \\
20.7 \sim 25.8\end{array}$ & $\begin{array}{r}11.339 \\
11.070 \\
10.953 \\
6.638\end{array}$ & $\begin{array}{l}4.72 \\
4.81 \\
4.83 \\
4.81\end{array}$ \\
\hline $10^{* 3}$ & 1452 & 1349 & 150 & $\begin{array}{r}1 \sim 5.3 \\
5.8 \sim 8.3 \\
8.8 \sim 16.2 \\
16.7 \sim 24.0 \\
24.5 \sim 31.4 \\
31.9 \sim 40.9\end{array}$ & $\begin{array}{r}7.105 \\
4.872 \\
13.206 \\
10.925 \\
11.635 \\
10.808\end{array}$ & $\begin{array}{l}4.73 \\
4.86 \\
4.82 \\
4.84 \\
4.82 \\
4.78\end{array}$ \\
\hline $11^{* 4}$ & 1451 & 1348 & 150 & $\begin{array}{r}1 \sim 6.0 \\
6.5 \sim 9.3 \\
9.8 \sim 13.3 \\
13.8 \sim 17.3 \\
17.8 \sim 25.6 \\
26.1 \sim 37.5\end{array}$ & $\begin{array}{r}5.835 \\
4.957 \\
6.722 \\
6.686 \\
16.108 \\
17.003\end{array}$ & $\begin{array}{l}4.58 \\
4.70 \\
4.65 \\
4.74 \\
4.74 \\
4.70\end{array}$ \\
\hline
\end{tabular}

* Stirring (100 r.p.m) *2 $1 \% \mathrm{KG}$ added $* 3 \quad 0.1 \% \mathrm{~S} * 4 \quad 0.3 \% \mathrm{~S}$ 


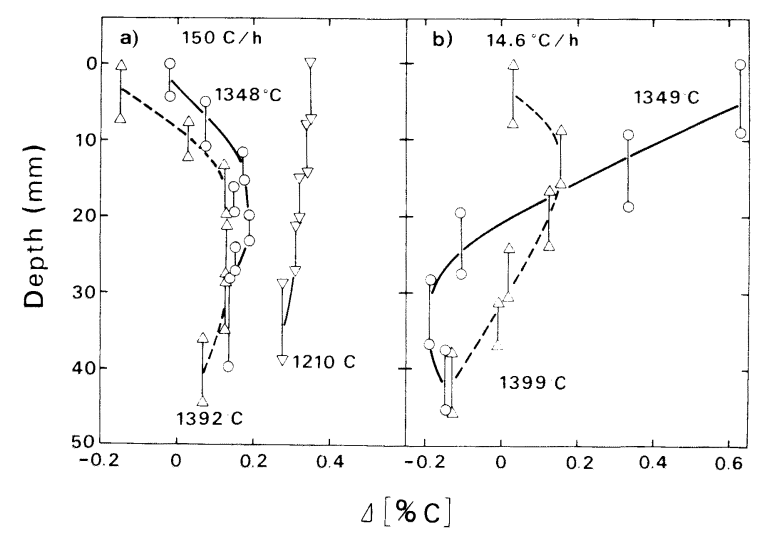

Fig. 1. Variation of $\Delta[\% \mathrm{C}]$ with depth as a function of quenching temperature at cooling rate of a ) $150^{\circ} \mathrm{C} / \mathrm{h}$ and b) $14.6{ }^{\circ} \mathrm{C} / \mathrm{h}$.

恋められるのは $\mathrm{KG} の$ 浮上しやすさをふしている。こ の $\mathrm{KG}$ の炭素飽和溶鉄中での浮上について, 周化温度, 冷却速度，摚抖㧍よび $\mathrm{S}$ 濃度の影響を検討した結果を 以下に述べる。

\section{$3 \cdot 1$ 固化温度および冷却速度の影響}

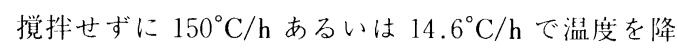
下させた実験について，(1)式で表される C 濃度差 $\Delta[\% \mathrm{C}]$ とメタル浴媣さの関係を Fig. 1 にホすす.

$\Delta[\% \mathrm{C}]=[\% \mathrm{C}]_{\text {anal. }}-[\% \mathrm{C}]_{\text {sat. }}$. (1)

ここで, $[\% \mathrm{C}]_{\text {anal. }}$ は Table 1 によえた全 $\mathrm{C}$ 分析值で ある. $[\% \mathrm{C}]_{\text {sat. }}$ は固化温度 $T_{1}\left({ }^{\circ} \mathrm{C}\right)$ における飽利 $\mathrm{C}$ 濃 度の計算値であり，(2)式から求められる。

$[\% \mathrm{C}]_{\text {sat. }}=1.30+0.00257 T_{1}-0.36[\% \mathrm{~S}]^{5}$

つまり, $\Delta[\% \mathrm{C}]$ はメタル各部での過飽利 $\mathrm{C}$ 量に 対応することになり，析出 Cが全量浮上した場命には $\Delta[\% \mathrm{C}]=0$ となる.

Fig. 1 中に六した温度は湖化温度を表す。また，試 料各部の長さを $\bigcirc \triangle \nabla$ 印を結んだ值線で表す。Fig. 1a) より, 冷却速度が $150^{\circ} \mathrm{C} / \mathrm{h}$ の場命, 固化温度が低いほ どメタル各部の $\Delta[\% \mathrm{C}]$ 傎は人きくなっている．湖化 温度が $1210^{\circ} \mathrm{C}$ では $\Delta[\% \mathrm{C}]$ 值はメタル表面に问かっ て徐々に増加する傾问を示すが, $1348^{\circ} \mathrm{C}$ および $1392^{\circ} \mathrm{C}$ ではメタル上部の $\Delta[\% \mathrm{C}]$ 值が中央部よりも低 くなっている.その理由は次のように考えた。メタル上 部を表面から約 $1 \mathrm{~mm}$ 研磨除去し，残りの部分について $\mathrm{C}$ 分析を行っているためメ夕ル表面曾の C 濃度は明ら かではないが, 試料を凝固させる際にメタル表面に $\mathrm{He}$ を吹き付けたことにより表面近傍のメタル浴が乱されて 析出 Cのメタル上への浮上が促進されたと思われる. 一方, 固化温度 $1210^{\circ} \mathrm{C}$ ではメ夕ル表面に $\mathrm{KG}$ が愿く 集積している上にメタルの粘性が高いため, He 吹付け の影響は少ないと考えられる. Fig. 1b）の冷却速度

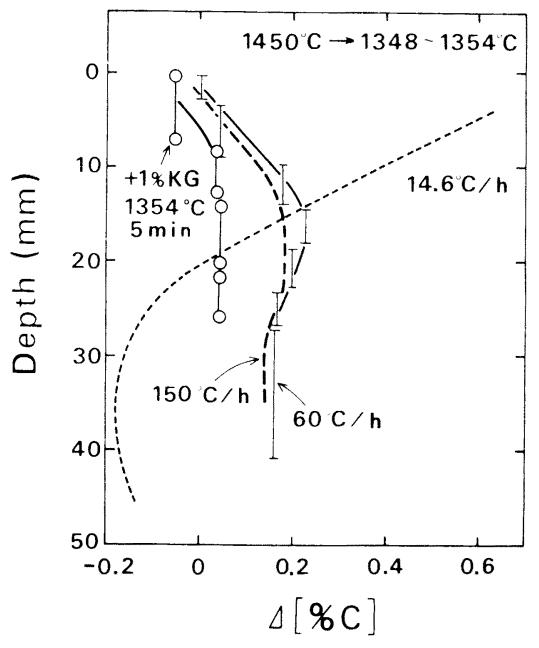

Fig. 2. Variation of $\Delta[\% \mathrm{C}]$ with depth as a function of cooling rate.

$14.6^{\circ} \mathrm{C} / \mathrm{h}$ の場令, 固化温度が低いうがメタル上部の $\Delta$ [\% C] 値が大きく, 析出 C が密集していることがわか る. 汹中, $\Delta[\% \mathrm{C}]$ 値が真, すなわち $\mathrm{C}$ 濃度が溶解度 よりも低值となっている部分もあるが, その理山は本研 究からは明らかでない。

固化温度を約 $1350^{\circ} \mathrm{C}$ と一分にして, 冷却速度を 14.6, 60 および $150^{\circ} \mathrm{C} / \mathrm{h}$ と変化させた実験結果を Fig. 2 に亦す。冷却速度が $60^{\circ} \mathrm{C} / \mathrm{h}$ と $150^{\circ} \mathrm{C} / \mathrm{h}$ ではメ夕ル中 の $\Delta[\% \mathrm{C}]$ 值分布に大きな差が認められないが, $14.6^{\circ} \mathrm{C} / \mathrm{h}$ では著しく異なる.

温度降下前にはメタル中のCは飽利であることから， 温度低下に伴う C 濃度の理㖮变化量 $\Delta[\% \mathrm{C}]^{*}$ は( 3 ) 式で表される。

$\Delta[\% \mathrm{C}]^{*}=[\% \mathrm{C}]_{\text {sat. }}^{*}-[\% \mathrm{C}]_{\text {sat. }}$ 


$$
=0.00257\left(T_{2}-T_{1}\right)
$$

ここで, $[\% \mathrm{C}]_{\text {sat. }}^{*}$ および $T_{2}$ は温度降下開始前の飽和 $\mathrm{C}$ 濃度および保持温度 $\left(1450^{\circ} \mathrm{C}\right)$ である。(1) 式およ び( 3 )式から，メタル各部の C 分析值 $[\% \mathrm{C}]_{i}$ および重 量 $W_{i}$ を用いて, メタルから分離した析出 $\mathrm{C}$ 量の理論 析出 $\mathrm{C}$ 量に対する割命 Floated C ratio (以下, FC 比 と称す)は(4)式で卢えられる.

$$
\begin{aligned}
\text { Floated C ratio } & =\frac{\sum_{i}\left([\% \mathrm{C}]_{\text {sat. }}^{*}-[\% \mathrm{C}]_{i}\right) \cdot W_{i}}{\sum_{i} \Delta[\% \mathrm{C}]^{*} \cdot W_{i}} \\
& \times 100(\%) \ldots \ldots \ldots \ldots \ldots \ldots \ldots \ldots \ldots \ldots \ldots \ldots \ldots \ldots \ldots \ldots \ldots \ldots
\end{aligned}
$$

$\mathrm{FC}$ 比 $=100(\%)$ は析出した C の全量がメタル上に浮 上分離し, $\mathrm{FC}$ 比 $=0(\%)$ は析出 $\mathrm{C}$ がメタル表面上に 全く浮トしないことを意味する。

Fig. 3 に FC 比と周化温度および冷却速度の関係を 示す。同一冷却温度では固化温度が低いほどメタルから 浮上分離した析出 $\mathrm{C}$ 量は多い. 同一固化温度では，冷 却速度が $60^{\circ} \mathrm{C} / \mathrm{h}$ と $150^{\circ} \mathrm{C} / \mathrm{h}$ で $\mathrm{FC}$ 比にほとんど差が ないが, $14.6^{\circ} \mathrm{C} / \mathrm{h}$ と極端に遅い冷却の場令にはメタル から分離した $\mathrm{KG}$ 量は著しく多くなる。この結果は前 述した顕微鏡観祭における固化温度, 冷却速度と $\mathrm{KG}$ の浮上状態の関係にも対忍する.

鱗片状である KG の浮上を調べるために次の実験を 行った，炭素飽和溶鉄の底部に $0.25 \sim 1.0 \mathrm{~mm}$ の大きさ の $\mathrm{KG}$ をメタル重量の $1 \%$ 装入し， $1354^{\circ} \mathrm{C}$ 一走で摚汼 してメタル中に分散させた後， $5 \mathrm{~min}$ 保持した。摚找終 了直後の $\mathrm{KG}$ の分散状態は調べていないが, メタル表 面に KG がわずかに浮上しているにすぎなかったこと から, 大部分の $\mathrm{KG}$ はメタル中に分散していたか, あ

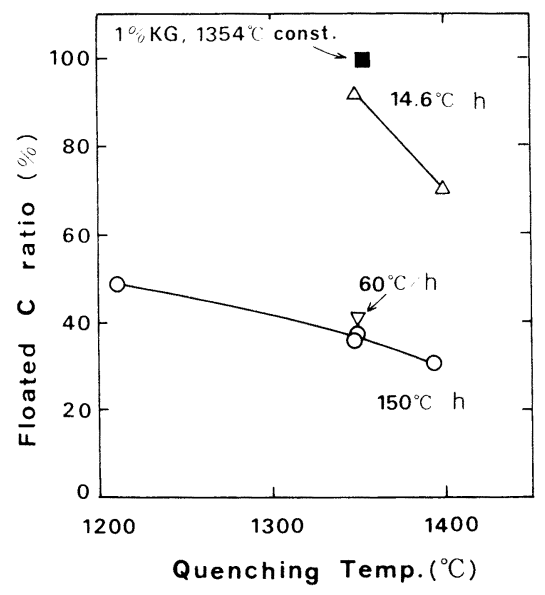

Fig. 3. Floated carbon ratios plotted against quenching temperature.
るいはメタル底部に残留していたと思われる。 5 min 保 持後にはメタル表面に浮上した $\mathrm{KG}$ 量は顕著であった. 実験後のメ夕ル各部での $\Delta[\% \mathrm{C}]$ 值および $\mathrm{FC}$ 比をそ れぞれ Fig. 2 および 3 に示す. Fig. 2 において，冷却 による C 析出の実験と比べメタル各部での $\Delta[\% \mathrm{C}]$ 值

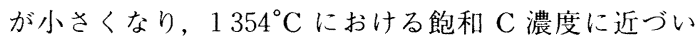
ている. Fig. 3 から, KGの 99\% がメタル上に浮上し ていた．析出によって生じた $\mathrm{KG}$ とは大きさが異なる ものの, KGの浮上速度は大きいことがわかる。

温度降下によりメタル中に析出した C がメタルとの 比重差のゆえに容易に浮上するならば，KGがメタル上 部にあり球状に近い析出 $\mathrm{C}$ がメタル全体に分布してい たことは説明されない.この点について，浮上速度と析 出 Cの大きさの関係から以下のように考察した.

粒子が静止浴中を重力方向に連動する場合，浮上方问 を正にとると, 定常状態に扔いて( 5 )式の運動方程式が 成り立つ.

$$
-\rho_{s} V g+\rho V g-\mathbf{C} A \rho u^{2} / 2=0
$$

ここで， $\rho_{s}, V, A, u$ はそれぞれ浮上する粒子の密度, 体積, 進行方向の断面積, 終末浮上速度である。 また, $\rho$ は浴密度，Cは抵抗係数， $g$ は重力加速度である．Cは 浴が非圧縮性であればレイノルズ数 $R e$ の関数となる.

( 5 )式の第 1 項は重力項, 第 2 項は浮力項, 第 3 項は抵 抗力項を表す.

$\mathrm{KG}$ 以外の析出 $\mathrm{C}$ を便宜的に直径 $d_{C}$ の球形であると 仮定すると, Stokes の法則からC を求めることにより, この球体の $u$ は(6)式で表される ${ }^{6)}$.

$u=g\left(\rho-\rho_{s}\right) d_{C}{ }^{2} /(18 \mu) \cdot$

ここで， $\mu$ は炭素飽和溶鉄の粘度7)である.

析出 $\mathrm{C}$ の直径と浮上速度の関係を $1300^{\circ} \mathrm{C}$ について

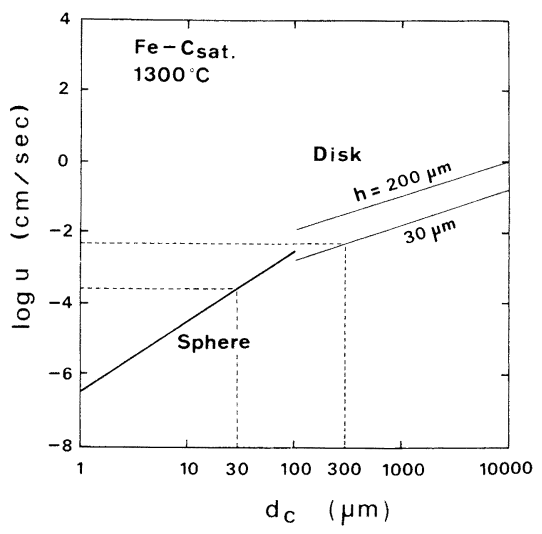

Fig. 4. Logarithms of floating rate plotted against diameter of carbon. 
Fig. 4 に示す. Stokes の法則が成り立つ $R e$ の值の範 囲から (6) 式は $d_{C} \lesssim 3 \mathrm{~mm}$ で適用可能である. $1400^{\circ} \mathrm{C}$ の計算結果は図に示した $1300^{\circ} \mathrm{C}$ の值の約 1.2 倍にす ぎず， $u$ の温度依存性はほとんど無視できる．Fig. 4 か ら, 直径 10 30 $\mu \mathrm{m}$ の球形に近い析出 Cについて $u$ の 值は $4 \times 10^{-5} \sim 3 \times 10^{-4}(\mathrm{~cm} / \mathrm{s})$ であり，小さいほど浮 上が荤く実験時間内に十分浮上しきれないことがわか る.

一方，KG は前報1)で示したように六角板状であるが， これを便宜的に直径 $d_{C}$, 厚さ $h$ の円板とみなし $(5)$ 式 を解くと( 7 )式が得られる.

$u=g\left(\rho-\rho_{s}\right) d_{C} \cdot h /(12 \mu)$

( 7 )式による KG の直径と浮上速度の関係を厚さ 30 $\mu \mathrm{m}$ および $200 \mu \mathrm{m}$ について Fig. 4 に示す. 厚さ $30 \mu \mathrm{m}$, 長さ $300 \mu \mathrm{m}$ の $\mathrm{KG}$ の $u$ の值は $5 \times 10^{-3}(\mathrm{~cm} / \mathrm{s})$ であり, 球状に近い析出 $\mathrm{C}$ よりも速やかに浮上することがわか

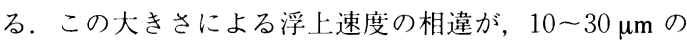
球状に近い析出 Cがメ夕ル全体に分布し，それよりも 大きい KG がメタル上部にある理由であると考えられ る。メタル表面近傍の C 打よび凝固時にメ夕ルから飛 散した C を SEM 観察したところ, 数百 $\mu \mathrm{m}$ 以上の球 状に近いC は認められなかった。同一冷却速度では固 化温度が低いほど，また同一固化温度では泠却速度が小 さいほど，固化温度に到達するまでの時間が長く，析出 C はメタル上部まで浮上することから，Fig. 3 の FC 比と周化温度抢よび泠却速度の関倸が説明される。特に KG は前述したように温度降下に伴って粗大化するた め，さらに浮上しやすくなる．KGの粗大化㧍よびメ夕 ルからの回收率向上を考えれば，大きい泠却温度差と低 い冷却速度が効果的である。

\section{$3 \cdot 2$ 揌拌の影響}

固化温度 $1348^{\circ} \mathrm{C}$, 冷却速度 $150^{\circ} \mathrm{C} / \mathrm{h}$ と一定にし, 摚 拌の影響を調べた結果を Fig. 5 に示す。約 100 r.p.m. で擋拌しながら冷却することによりメタル各部間の C 濃度差が小さくなりほぼ一定になると共に， $1348^{\circ} \mathrm{C} に$ 扔ける飽和 $\mathrm{C}$ 濃度に近づいている. Fig. 3 に扔いて冷 却速度 $60^{\circ} \mathrm{C} / \mathrm{h}$ および $150^{\circ} \mathrm{C} / \mathrm{h}$ で固化温度約 $1350^{\circ} \mathrm{C}$ の場合の FC 比はそれぞれ $41 \%$ および $35 \%$ であった が，冷却中の擋拌により FC 比はいずれの場合も $81 \%$ まで増加した、顕微鏡観察によれば，メ夕ル中に $\mathrm{KG}$

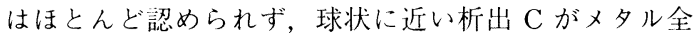
体に分布していた。このことから，摚拌は冷却速度に関 係なく，特に KG の浮上に効果があることになる.

Fig. 2 に示した $1354^{\circ} \mathrm{C}$ 一定で $\mathrm{KG}$ の浮上を調べた 実験結果をFig. 5 に与える。この実験では一定温度で

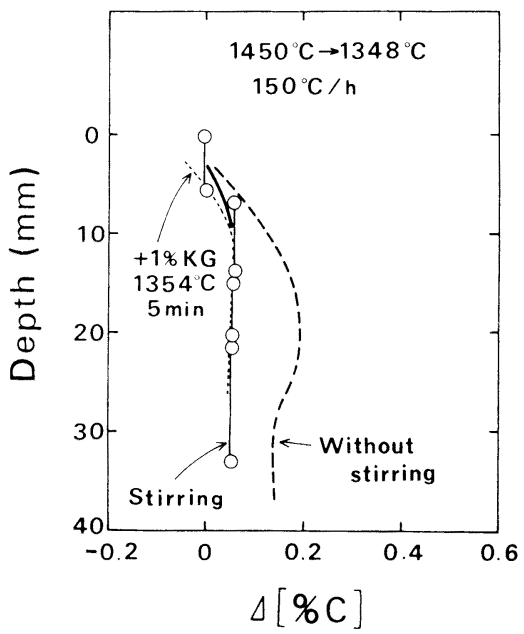

Fig. 5. Effect of stirring on the variation of $\Delta[\% \mathrm{C}]$ with depth.

過飽和 CとしてKG を加えており，温度降下がないた め $\mathrm{KG}$ 以外の球状に近い析出 $\mathrm{C}$ が存在しないものであ る. Fig. 5 から明らかなように，この実験結果は摚抖 しながら $150^{\circ} \mathrm{C} / \mathrm{h}$ で冷却した際の $\mathrm{C}$ 濃度分布とほぼ同 じであった. Fig. 3 より，析出した KG と大きさは異 なるものの，0.25 1.0 $\mathrm{mm}$ の大きさの $\mathrm{KG}$ のみの浮上 における FC 比は $99 \%$ であり，擋找しながら冷却した 実験結果よりも $\mathrm{FC}$ 比は $18 \%$ 高い。このことから, 球 状に近い析出 C の浮上は Fig. 4 にも示したと扮り遅 く，擋拌によっても十分ではないことがわかる.

\section{$3 \cdot 3$ 硫黄の影響}

界面活性効果を有することが知られている S は溶銑 中に $0.03 \sim 0.05 \%$ 含まれており，析出 Cの形状およ び浮上に影響をおよぼすことが考えられる。

固化温度的 $1350^{\circ} \mathrm{C}$, 冷却速度 $150^{\circ} \mathrm{C} / \mathrm{h}$ としてメタル 中の $\mathrm{S}$ 濃度を $0.1 \%$ および $0.3 \%$ とした実験結果を Fig. 6 に示す。メ夕ル中の $\mathrm{S}$ 濃度が上昇するにつれて メタル各部の $\mathrm{C}$ 濃度は固化温度での飽和值に近づいて いる. FC 比と S 濃度との関係を Fig. 7 に与える. メ タル中の $\mathrm{S}$ 濃度が増加するにつれてメタル上に浮上し た C 量は多くなることがわかる。

これらの試料のメタル表面近傍の顕微鏡写真を Photo. 1 に示す. S を含まない場合 $(\mathbf{a}))$ と比べて S 濃度が b） $0.1 \% \mathrm{~S}$ および c) $0.3 \% \mathrm{~S}$ のいずれも KG は 細くなりわん曲，分岐が著しくなっている，従来，S の界面活性効果によってこのような現象が生じることが 報告されており ${ }^{8)}$, Photo. 1 のKG の形状変化と一致す 
る。固化時にるつぼから飛散した C は，0.1\% S 場合 は厚さ $5 \sim 10 \mu \mathrm{m}$, 長さ $50 \sim 300 \mu \mathrm{m}, 0.3 \% \mathrm{~S}$ では厚さ $2 \sim 5 \mu \mathrm{m}$, 長さ $30 \sim 150 \mu \mathrm{m}$ のわん曲を伴った片状黒鉛 が多層に重なり合ったものであった。

浮上速度を計算によって求める際にはわん曲および分 岐を有する C を球あるいは円板として取り扱うことが できないため, Fig. 7 の FC 比におよぼす S の影響を

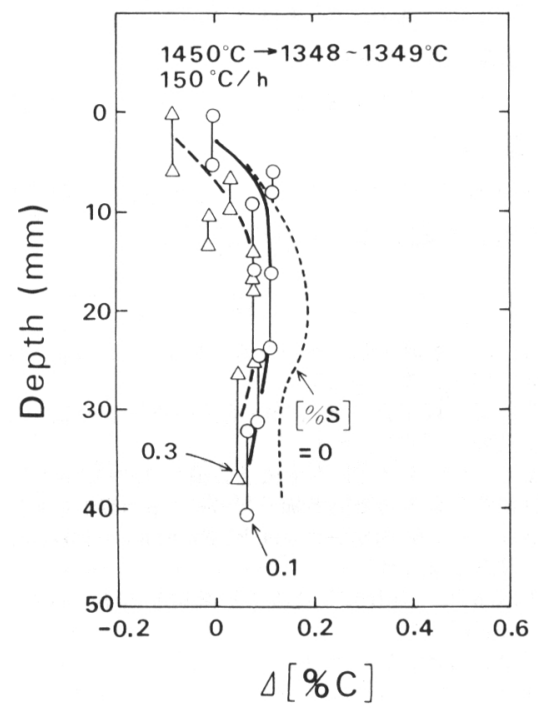

Fig. 6. Effect of sulfur content in metal on the variation of $\Delta[\% \mathrm{C}]$ with depth.
浮上速度の面から説明することはできないが，この $\mathrm{KG}$ 形状の変化が浮上速度を大きくしていることが考えられ る.また，炭素飽和溶鉄中に $\mathrm{S}$ が添加されることによ りメタルの密度が微かに上昇する ${ }^{2)}$ と共に粘性が著しく 低下する ${ }^{9)}$ こも， FC 比が増加する理由と考えられる.

実際の溶銑に含まれている不純物による $\mathrm{KG}$ 形状の 変化を調べるために， $0.6 \% \mathrm{Si}-0.7 \% \mathrm{Mn}-0.1 \% \mathrm{P}-0.05$ $\% \mathrm{~S}$ を含む炭素飽和溶鉄を $1450^{\circ} \mathrm{C}$ から $1124^{\circ} \mathrm{C}$ まで $14.6^{\circ} \mathrm{C} / \mathrm{h}$ で冷却した。 その結果，これら不純物を含ま ない炭素飽和溶鉄から析出した KG の厚さが 120 ２00

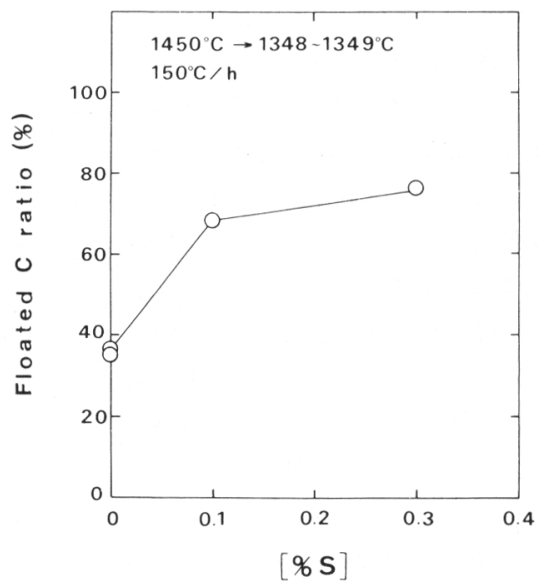

Fig. 7. Floated carbon ratio plotted against sulfur content in metal.

\section{$1450^{\circ} \mathrm{C} \rightarrow 1348 \sim 1349^{\circ} \mathrm{C}, 150^{\circ} \mathrm{C} / \mathrm{h}$}

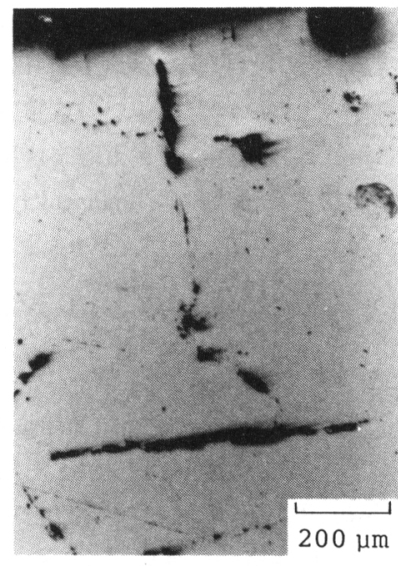

a) $0 \% \mathrm{~S}$

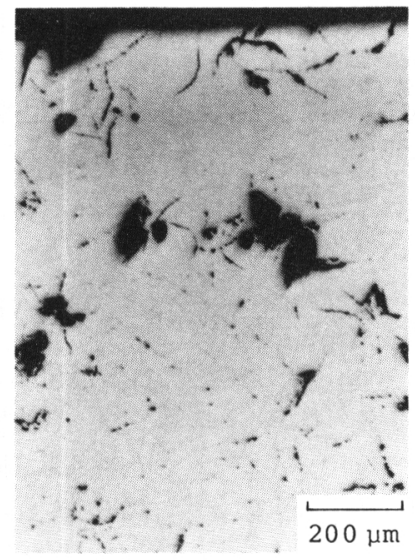

b) $0.1 \% \mathrm{~s}$

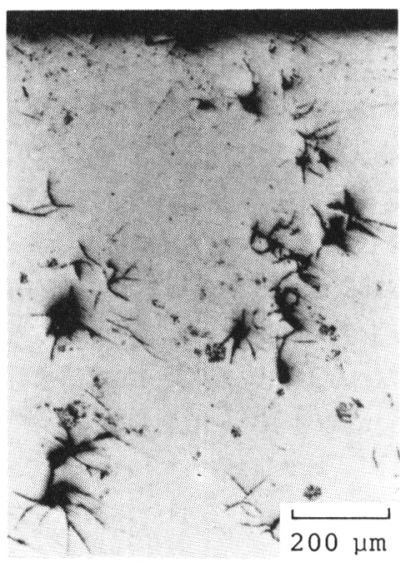

C) $0.3 \% \mathrm{~s}$

Photo. 1. Effect of sulfur content in metal on the shape of carbon precipitated from metal phase. 
$\mu \mathrm{m}$ であったのに対し，30～ $50 \mu \mathrm{m}$ と薄くなっていた KG の形状におよぼす $\mathrm{S}$ の影響は $0.01 \%$ でも䜑められ るとする報告 ${ }^{8)}$ があるが, $\mathrm{Si}, \mathrm{P}$ が炭素飽和溶解度を

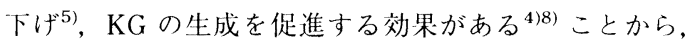
実際の溶銑から生じた KGの形状におよほすす不純物の 影響は複雑である。

\section{KG の回収}

本研究結果抢よび前報1) で示した $\mathrm{KG}$ のスラグ層か らの浮上分離に関する研究結果をあわせて, KG の有効 な回收法については以下のように考えられる。

メタル中での $\mathrm{KG}$ の成長抢よび浮上については，高 炕からの出銑後の温度降下が大きいほど，また，冷却速 度が小さいほど有効である。後者は溶銑鍋あるいは卜 ピードカーの保温性の改善により叮能であろうが，前者 は製鋼工程との関連で制限を受ける．KGの浮上に関し て擋汼は効果があり，スラグーメタル界面のメタル側に 集積した KG が擋找によってスラグ上に浮上しだここ とからも，搅汼は $\mathrm{KG}$ の回収に欠かせない。

いったんスラグ中に入り达んだ $\mathrm{KG}$ は付着していた メタル粒を脱落させながら自然に浮上するが，スラグ中 に酸化鉄があれば KGは燃焼してしまう。スラグの粘 性が低いほど KG は速やかにスラグ中を浮上する。特 にソーダ系スラグ中を浮上する場命は $\mathrm{Na}_{2} \mathrm{O}$ と $\mathrm{KG}$ の 反応も考えられるが，KG 表面のメタル粒拉よび脱珪ス ラグ粒が除去されるので，新たに付着したソーダ系スラ グを水処理で落とすことにより高品位の KGを得るこ とができると思われる，KGの高純度化について著者ら が行った研究 ${ }^{10)}$ によれば， $\mathrm{Na}_{2} \mathrm{O}-\mathrm{B}_{2} \mathrm{O}_{3}$ 系フラックスを 用いて KG を洗浄し，湿式処理でフラックス分を除去
することにより，周定 C 濃度 $99.95 \%$ の KG が得られ ている.

\section{5. 結 \\ 言}

炭素飽和浴鉄中の析出 Cの浮上について，冷却温度 差，冷却速度，摚汼拉よび $\mathrm{S}$ 濃度の影響老調べ，以下 の結論を得た。

1 ) 冷却温度差が大きく冷却速度が小さいほど KG は 厚く長くなった。また，メタル上部まで浮上し，メタル から浮上分離した C 量は多くなった。

2 ) メ夕ル浴を擋抖することによりメタル中の $\mathrm{KG} の$ 浮上が促進された。

3 )メタル中の $\mathrm{S}$ は析出 $\mathrm{C}$ の浮上を促進した。また, 析出 Cの形状を細く短くする作用があった。

\section{文献}

1) 井上 亮, 水渡英昭, 米谷章義, 橋本 透: 東北大学選研 彙報, 43 (1987), p. 15

2 ）足立。彰、森田善一郎: 溶鉄・溶滓の物性佔便覧（日本鉄 鋼協会編）(1972)，p. 1

3 ）金属データブック（日本金属学丟編）（1974），p.9[丸善]

4 ）鋳物便覧（日本鋳物協会編）（1978），p.837 [丸善]

5 ) $F$. Neumann, $H$. Schinck and $W$. Pattirson: Giesserei, $23(1959)$, p. 1217

6 ）八田四郎次, 前田四郎: 化受:1学概論 (1973), p. 273 [其立出版]

7) M. I. Avaliani, A. B. Kaplun, M. F. Kritho and I. A. VAShukov: Izv. Chernaya Met. (1977) 2, p. 123

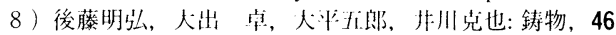
(1974), p. 1054

9 ) $N$. E. Bodakin, B. A. Baum, G. V. Tyagunov and $M . N$. KuSHNIR: Izv. Akad. Nauk SSSR, Metally (1977) 2 , p. 71

10）井上，筧，水渡英昭: 東北大学:選研菓報，44（1988）, p. 214 